ADDIN, Volume 13, Number 2, August 2019

\title{
Elasticity of Understanding of M. Syuhudi Ismail on Hadith About the Threats for Painter
}

\author{
Rohmansyah
}

Universitas Muhammadiyah Yogyakarta, Indonesia

rohmansyah@umy.ac.id

\begin{abstract}
Painting or drawing is a penchant for some humans, especially pictures or paintings that are seen as beautiful as images of humans, animals, plants, and others. However, on the other hand it becomes a problem if the painting is worshiped or cultured. This paper seeks to present the elasticity of the understanding of the hadith of M. Syuhudi Islam concerning threats to painters by using library research and descriptive-analysis approaches from the sociological aspects of knowledge and historical-sociological. The findings show the elasticity of M. Syuhudi Ismail in understanding the hadith of painting. Hadith of painting had been understood temporally and locally which occurred when the hadith was delivered by Rasulullah when the new societies came out of idolatry worshiping idols or statues including animate images so that hadiths appeared on the prohibition of painting or drawing because they feared they would do the same again. According to Syuhudi Ismail, the prohibition was seen from 'illah al-bukm (legal cause), namely worshiping and culturing paintings or drawings so that in today's context it is permissible for painters to aim not to be worshiped or cultured but to be used as a field of economic endeavors to fulfill everyday life.
\end{abstract}

Keywords: Elasticity, Understanding, M. Syubudi Ismail, Painter. 


\section{Abstrak}

ELASTISITAS PEMAHAMAN M. SYUHUDI ISMAIL TERHADAP HADIS TENTANG ANCAMAN BAGI PELUKIS. Melukis atau menggambar adalah suatu kegemaran sebagian manusia terutama gambar atau lukisan yang dipandang indah seperti gambar manusia, hewan, tumbuhan, dan lain-lain. Namun, di sisi lain menggambar menjadi problem apabila lukisan tersebut disembah atau dikultuskan. Tulisan ini berusaha menyajikan elastisitas pemahaman hadis M. Syuhudi Islam tentang ancaman bagi pelukis dengan menggunakan penelitian library research dan pendekatan deskriptif-analitis dari aspek sosiologi pengetahuan dan historis-sosiologis. Hasil temuan menunjukan elastisitas M. Syuhudi Ismail dalam memahami hadis tentang melukis. Hadis tentang melukis dipahami secara temporal dan lokal yang terjadi saat hadis disampaikan Rasulullah dan masyarakat baru keluar dari kemusyrikan menyembah berhala atau patung termasuk gambar bernyawa sehingga muncul hadis tentang larangan melukis atau menggambar karena dikhawatirkan mereka kembali melakukan hal yang sama. Menurut Syuhudi Ismail, larangan tersebut dilihat dari illah al-bukm (sebab hukum), yakni menyembah dan mengkultuskan lukisan atau gambar sehingga dalam konteks hari ini diperbolehkan bagi pelukis dengan tujuan tidak untuk disembah atau dikultuskan, tetapi dijadikan sebagai ladang usaha ekonomi untuk memenuhi kebutuhan hidup sehari-hari.

Kata Kunci: Elastisitas, Pemahaman, M. Syubudi Ismail, Pelukis.

\section{A. Introduction}

Surah is a picture or painting made by humans on paper, cloth, and others which usually takes the form of humans, animals and plants. In the modern era, drawing is no longer manually, they use digital technology such as cameras, computers and various other tools. However, it is different from paintings that can only be painted by humans who have special talents in the field of painting using painting tools. 
Drawing or painting is basically a mubab deed for humans as a form of creativity. ${ }^{1}$ However, on the other hand there are differences of opinion among the scholars, both classical and contemporary about legal issues of drawing or painting. The earlier (classical) scholars were more likely to be textual in understanding hadith, such as al-Nawawi's opinion, drawing animals (animate creatures) was illegitimate based on ijma' of scholars. ${ }^{2}$ Scientists from the followers of Imam asy-Syafi'i state that is is makrub if they draw an animate animal. Whereas the contemporaneous scholars such as Yusuf alQaradhawi said that painting something to worship or not worship but glorified it like the image of the king, the zu'ama' and others to emulate God's creation, it was forbidden and sinful. ${ }^{3}$ This can be understood, if just drawing without any purpose whatsoever, is not a problem. But drawing the animate creatures like humans or the animals, the scholars agree that the law is haram.

The problem with this picture is that it is very serious because the implication is very large for the painter namely al-mushawnir (the person who drew or painted), he was threatened with torture as stated in one hadith narrated by al-Bukhari, "People who draw or paint will get very powerful tortured and in the Hereafter is told to bring to life the animal that he had drawn at the time in the world."

The expression of the hadith above raises a diverse paradigm, some of them have understood the hadith textually and there are also some of them understand the hadith contextually. If the hadith is understood in a textual manner, it will cause restlessness for the perpetrators of tashwir, because it can threaten their careers as

${ }^{1}$ Painting is an act of muamalah that is permissible or lawful to be done by everyone as long as there is no argument that prohibits it based on the rules of ushul figh, "Basically mu'amalah is permissible." See Wahbah az-Zuhaili, al-Fiqh al-Islami wa Adillatuhu (Damaskus: Dar al-Fikr, 1984), 166.

${ }^{2}$ Zainuddin bin Najim al-Hanafi, al-Babr ar-Ra'iq Syarb Kan₹, ad-Daqaiq (Beirut: Dar al-Kutub al-'Ilmiyyah, 1997), 29.

${ }^{3}$ Yusuf al-Qaradhawi, al-Halal wa al-Haram fi al-Islam (Kairo: Maktabah Wahbah, 1997), 105.

${ }^{4}$ Muhammad bin Isma'il bin Ibrahim bin al-Mughirah al-Ju'fi al-Bukhari, Shabih al-Bukhari, Volume 8 (Beirut: Dar asy-Syuq an-Najah, 1422), 167. 
livelihoods to make ends meet. While the contextual circles, trying to explain some aspects related to the hadith threat for perpetrators of tashwir so that they continue to survive by cultivating the art of drawing and painting both in the national and international spheres to become promising income as long as it does not violate the rules of religion.

The polemic can be solved by understanding the hadith elasticly by taking a middle way between two different understandings. One of the popular figures of Indonesian hadith in the field of wellknown elastic hadith is M. Syuhudi Ismail, he tried to do elastic understanding from the point of view of the hadith context in the past and attract it in the present as written in his book entitled M. Syuhudi Ismail, Hadis Nabi yang Tekstual dan Kontekstual (Textual and Contextual Prophets Hadiths). ${ }^{5}$

Previous research was Fithriady Ilyas and Ishak bin $\mathrm{Hj}$. Sulaiman, "Muhammad Syuhudi Ismail (1943-1995): Tokoh Hadis Prolifik, Ensklopedik, dan Ijtihad". Both of them examined the figure of Syuhudi Ismail by using a research library whose results explained that Syuhudi Ismail was a productive person who produce to 59 scientific and moderate works such as allowing women to become leaders and not allowing plastic surgery for beauty. ${ }^{6} \mathrm{M}$. Syuhudi's thoughts about also written by Hasan Su'aidi who try explores the similarity point of Syuhudi Ismail's contextualization method with hermeneutical theories try explores the similarity point of Syuhudi Ismail's contextualization method with hermeneutic theories. ${ }^{7}$ Speaking of hermeneutic studies of many figures studied from the aspect of hadith thinking, one of them was Ali Mustafa

${ }^{5}$ M. Syuhudi Ismail, Hadis Nabi yang Tekstual dan Kontekstual (Jakarta: Bulan Bintang, 2009).

${ }^{6}$ Fithriady Ilyas and Ishak bin Hj. Sulaiman, "Muhammad Syuhudi Ismail (19431995): Tokoh Hadis Prolifik, Ensklopedik, dan Ijtihad," Jurnal Ilmiah Islam Futura 17, no. 1 (2017), 1-33.

${ }^{7}$ Hasan Su'aidi, "Hermeneutika Hadis Syuhudi Ismail," RELIGIA 20, no. 1 (2017), 33-48. 
Yaqub. ${ }^{8}$ The next, understanding of hadith M. Syuhudi Ismail also concluded by Amrulah that there are three theoretical considerations, namely aspects of space and time, social and cultural change.?

This research is different from the research above, because the researcher will discuss in detail about aspects of his understanding of the hadith and analyze whether there is influence by the previous scholars both classical and contemporary and explain their opinions that are pro and contra of his thoughts especially regarding the understanding of hadith threat to al-mushawwir (painter).

Based on the description above, this research is very important to be raised in a hadith study considering the emergence of various problems that occur especially for those who are trapped in a textual understanding without seeing various aspects that occur in it. The researcher will try to do the library research method with a descriptive-analysis approach by presenting the understanding of M. Syuhudi Ismail about the threat of tashwir (painter) perpetrators and analyze his opinion why he has an elastic understanding by presenting various opinions of other scholars both pro and contra on his understanding.

The approach used in this research is a sociology of knowledge approach which is a new science that is a branch of sociology that studies the reciprocal relationship between thinking and society. The sociology of knowledge focuses on social conditions or the existence of knowledge. Scholars in this field are not limited to the sociological analysis of the area of cognition as seen in the term, but also practically observe intellectual products, such as philosophy, ideology, political doctrines, and theological thought. Therefore, the sociology of knowledge seeks to connect ideas with the reality of society and examine the historical settings in which these ideas are

\footnotetext{
${ }^{8}$ Rohmansyah, "Hadith Hermeneutic of Ali Mustafa Yaqub," KALAM 11, no. 1 (2017), 187-214.

9 Amrulloh, "Kontribusi M. Syuhudi Ismail dalam Kontekstualisasi Pemahaman Hadis," Mutawatir: Jurnal Keilmuan Tafsir Hadis 7, no. 1 (2017), 76-104.
} 
reviewed and accepted. ${ }^{10}$ This approach cannot be separated from the historical approach, namely an approach that discusses an event by looking at the elements of place, time, object, background, and historical actors. This is very needed in understanding religion, because religion itself comes down in concrete situations related to the social conditions of society. This is related to the text of the hadith that came to the Prophet relating to the events that occurred (asbab al-wurud micro), but this is very limited so it needs a new theoretical approach, namely the socio-historical approach (asbab al-wurud) macro with wider and unlimited scope in the Prophet's hadith.

Fazlur Rahman explicitly said that the historical approach must be accompanied by a sociological approach specifically photographing social conditions that occur at the time the text of the Qur'an or hadith brought. In this case, the understanding of the Al-Qur'an and hadith texts shows the elasticity of development without removing its historical elements so that a text of Al-Qur'an or hadith will always be accepted anytime and anywhere. Thus, the elements of universality and flexibility of the Qur'an or hadith are also preserved. ${ }^{11}$

The historical approach linked to sociology until became a historical-sociological approach as cited by Musahadi HAM. This approach is very urgent to apply in understanding the hadith about law which is always accompanied by ratio-legis (legal or objectives goals) with which to understand the hadith by looking at the background and situation occurred during the time of the Prophet and Muslims that is by the Muslims of the present hadith are reinterpreted according to their times. The steps taken in the historical-sociological approach are: First, understanding the meaning of the hadith text. Second, understand the hadith background and its situation (asbab al-wurud). Third, understand the hadith according to

${ }^{10}$ Muhyar Fanani, Metodologi Studi Islam: Aplikasi Sosiologi Pengetahuan Sebagai Cara Pandang (Yogyakarta: Pustaka Pelajar, 2010), 32.

${ }^{11}$ Sibawaihi, Hermeneutika Alquran Fazlur Rahman (Bandung: Jalasutra, 2007), 53. 
the Qur'an's instructions by paying attention to the moral ideal of the hadith. Fourth, reformulate the law from moral ideal principles that can be applied in life by looking at the sociological aspects of the present. This is what according to Fazlur Rahman is called the thawing of the hadith to be the living Sunnah. ${ }^{12}$ In other languages, the Sunnah is a living tradition that is inherited and drawn up to the time of the Prophet and verbalized into hadith. ${ }^{13}$

\section{B. Discussion}

\section{Intellectual Biography of Muhammad Syuhudi Ismail}

Muhammad Syuhudi Ismail was born in Lumajang, East Java on April 23, 1943. He was born to two married couples namely H. Ismail and Sufiyatun. Both are religious devotees. His father's full name is Ismail bin Mistin bin Soemoharjo came from the Madurese tribe and died in 1994 AD, his mother was named Sufiyatun binti Ja'far who was of Javanese origin and died in 1993 M. His grandfather, M. Ja'far was a warrior from Ponorogo and had became a Dutch police officer. Therefore, he came from the descendants of people who were rich and were religious and mixed between Madurese and Javanese so that he could be said to have two characteristics of Madura and Javanese. ${ }^{14}$

As for the lineage of his descendants, he was descended from a moderate scholar namely Ismail who was originally a follower of Masyumi and then broke out and joined Nahdlatul Ulama. He chose to follow Masyumi who is a member of the Muhammadiyah union in terms of the problem of building the mosques and madrassas even though it is for NU residents.

\footnotetext{
${ }^{12}$ Musahadi HAM, Hermeneutika Hadis-hadis Hukum: Mempertimbangkan Gagasan Fazlur Rabman (Semarang: Walisongo Press, 2009), 340.

${ }^{13}$ Mun'im Sirry, Tradisi Intelektual Islam: Rekonfigurasi Sumber Otoritas Agama (Malang: Madani, 2015), 13-27; Fazlur Rahman, Islamic Methodology in History (Islamabad: Islamic Research Institute, 1998), 13-27.

${ }^{14}$ M. Syuhudi Ismail, Kaidab Kesabihan Sanad Hadis: Telaah Kritis dan Tinjuan dengan Pendekatan Ilmu Sejarah (Jakarta: Bulan Bintang, 2005), 269.
} 
At the age of 22 years around 1965, he married Nurhaedah Sanusi, a girl of Bugis blood (Sidrap) and was blessed with four children and three survivors, namely: Yunida Indriani, Kherul Muttaqin, and Muhammad Fuad Fathoni. Around the beginning of 1972, his beloved wife passed away. Then at the end of that year, he married Nurhaedah Sanusi's sibling named Habibah Sanusi. From his marriage he was blessed with two sons namely: Muhammad Ahsan and Muhammad Irfan. ${ }^{15}$

During his life Muhammad Syuhudi Ismail was known as a figure of scholars who had extensive knowledge and sharp thoughts and he wrote in a book entitled hadith which is textual and contextual and various other works especially in the field of hadith. Muhammad Syuhudi Ismail is an academic and having received a tertiary education and certainly cannot be separated from the guidance of his teachers so that it then influences his thinking patterns. The teachers are: (a) his own father H. Ismail, to him he learn to read the Qur'an; (b) Kiai Mansur, to him he studied religion; (c) Madjidi a prominent figure of Muhammadiyah in Ujungpandang, to him he learn a lot about religion; (d) Harun Nasution, a Western alumni, to whom he learned a lot about research, religious knowledge and understanding of hadith; (e) M. Quraish Shihab, a Middle Eastern alumni, famous interpreter at Syarif Hidayatullah State Islamic University, Jakarta, to him he was studying religion systematically and thematic interpretations of understanding; (f) Said Agil Husain al-Munawwar was a Middle Eastern alumni, to him he studied in college and received many input of knowledge about the study of hadith and the methodology of understanding hadith. So, it is not surprising if the thoughts and understanding of hadith of Syuhudi Ismail tend to be contextual.

Muhammad Syuhudi Ismail finally died on Sunday, November 19, 1995 at Cipto Mangunkusumo Hospital, Jakarta. Then, he buried

${ }^{15}$ Syarifah Hasanah, "Hermeneutika Hadis Syuhudi Ismail," in Hermenentika AlQur'an dan Hadis, ed. Sahiron Syamsuddin (Yogyakarta: eLSAQ, 2010), 362-363. 
at the Arab Islamic Cemetery, Bontoala, Ujungpandang on Monday, November 20, 1995.

His education was starting from the Sekolah Rakyat Negeri in Sidorejo Lumajang, East Java, it was completed in 1955. Then he continued his education in the State Religion Teacher Education (PGAN) for 4 years in Malang and completed in 1959, State Islamic Judge Education (PHIN) in Yogyakarta was completed in 1961, Faculty Sharia, State Islamic Institute (IAIN) Sunan Kalijaga Yogyakarta Branch Makassar (now an IAIN) Alaudin Makassar in Ujungpandang was completed in 1973, Yogyakarta Full-Time Study (SPS) academic year 1978-1979, S2 Master Study Program in Postgraduate Faculty of Syarif Hidayatullah IAIN Jakarta was completed in 1985, and his last education was S3 Doctoral Program at the same Institution until it was completed in 1987 with the dissertation title "Kaidah Kesahihan Sanad Hadis: Telaah Kritis dan Tinjauan dengan Pendekatan Ilmu Sejarah".

His written works with his hands in the form of papers, research, speeches, articles, and dictates include: "Tempus Delictus in the 1965 Islamic Criminal Law" and "Application of the Qibla Direction in the Construction of the Mosque" in 1982; "Determining the Direction of Qibla and the Time of Prayer" in 1987; "Hisab Rukyat Early in the Month of Hijriyah and How to Make a Calendar in 2000 and 2222 AD" in 1990; "Table of Calendar Year 1-500 Hijriyyah and Its Comparison with the Year 1992 AD"; dictate: "Astronomy 1" in 1981; papers: "Around the Beginning of Reckoning" in 1977; "Prayer Times and Qibla Direction" in 1977; "The Implementation of Reckoning and Rukyah Early" in 1982; "Solar Eclipses According to the Reckoning and Hadith of the Prophet" in 1982; "Around the Source of Differences in the Initial Determination of the Month for the Hijriah Year (Qamariyah) among the Reckoning Experts and Rukyah Experts: Review According to Astronomy" in 1994; "al-Maturidi: His Life History and Thoughts"; "Socrates and His Philosophy"; Syah Waliyullah 
ad-Dahlawi: the History of His Life and Thought"; Ottoman Young: Important Leaders and Thoughts"; "Happiness According to Aristotle and Islam"; "Syihabuddin Syuhrawardi al-Maqtul"; "Syah Waliyullah ad-Dahlawi: Reformation of Islamic Thought in India"; and books that become standard courses include: Introduction to Science Hadith in 1987; The Validity of the Hadith Sanad in 1988; Practical Ways of Looking for Hadith in 1991: Sunnah According to Its Defenders and Efforts to Preserve Sunnab by Its Defenders in 1991; Sunnah According to Its Deniers and Sunnah Preservation Efforts by Its Defenders in 1991; Hadith Research Methodology in 1992; Textual and Contextual Prophetic Hadith: Ma'anil Hadith Review of Universal, Temporal, and Local Islamic Teachings in 1994; The Prophet's Hadith According to Its Defenders, Deniers, and Forgers in 1995.

\section{The Elasticity of Understanding of M. Syuhudi Ismail about the Hadith Threat of the Actor Tashwir (Painter)}

M. Syuhudi Ismail in understanding elastic hadith which means it is not rigid and tends to be moderate, this is seen when he understands the hadith of the Prophet. One of the hadiths raised in this discussion is the hadith about the threat to the perpetrators of tashwir (al-mushawwir) as follows:

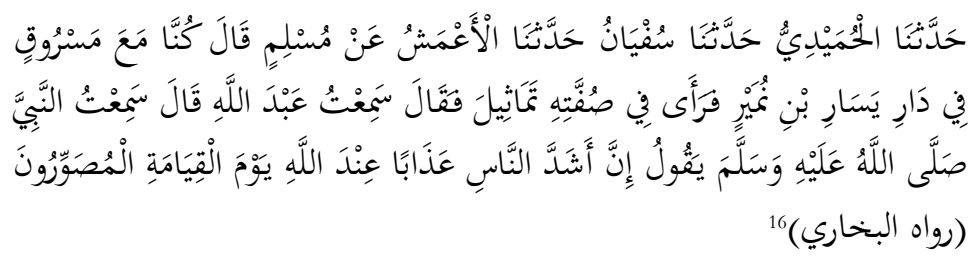

${ }^{16}$ Muhammad bin Ismail al-Bukhari, Sahih al-Bukhari, volume 7 (Beirut: Dar Ibnu Katsir, 2002), 167. See also in Muslim, there are three lines of narration of traditions sourced from three Companions of the Prophet, Abu Muslim bin al-Hajaj al-Qusyairi al-Naisaburi al-Husain, Shabih Muslim, volume 3 (Riyad: Bait al-Afkar ad-Dawliyah, 1998), 1.670. Imam Ahmad bin Hanbal, there are three lines of transmission of traditions sourced from three of the Prophet's friends. See Imam Ahmad bin Hanbal, Musnad al-Imam Ahmad bin Hanbal, volume 10 (Beirut: al-Muassasah ar-Risalah, 2001), 373. See Muhammad bin Hibban bin Ahmad Abu Hatim at-Taimi al-Busti, Shabib Ibn Hibban bi Tartib Ibn Balban, volume 13 (Beirut: al-Muassasah ar-Risalah, 1993), 159. 
"Having told us al-Humaidi, having told us Sufyan, having told us al-A'masy from Muslims said: we were with Masruq at the house of Yasar bin Numair, then he saw at his sufah a picture and then he said, I heard Abdullāh say, I heard the Prophet saw. said: actually, the most terrible man of his torment with Allah on the Day of Judgment is al-mushawwir (the person who painted)." (H.R. al-Bukhari)

This hadith besides being narrated by al-Bukhari was also narrated by Muslims and Ahmad bin Hanbal. The hadith which are meaningfully narrated are quite a lot which explains the prohibition of painting animate creatures. It is said that for the painter on the Day of Judgment, he will be required to turn on the picture he painted and the Angels will not enter the house if there are paintings inside it. ${ }^{17}$

When viewed from the side of language, the threat of hadith for painters does not only use the word al-mushawwirun as a form of ism al-fa'il, but also uses the word shawwara as a form of fi'il al-madi (past verb form) which shows something that has been done. It means that the work of painting if it has been done then he is exposed to the threat of Allah, but if the work has not been done, only to the intention to do it but does not happen, it means he is not subject to the threat of hell torture. As in the editorial of the following hadith:

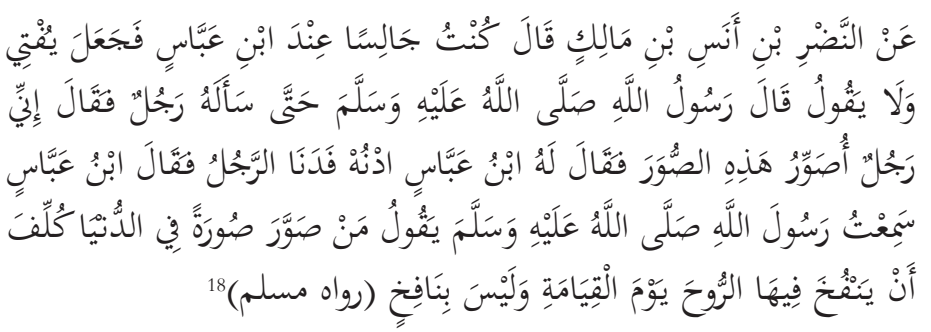

${ }^{17}$ M. Syuhudi Ismail, Hadis Nabi yang Tekstual dan Kontekstual, 36.

${ }^{18}$ Al-Husain, Shabih Muslim, volume 3, 1.671. Sulaiman bin al-Asy'as asSijistani, Sunan Abi Dawnd, volume 4 (Riyad: Bait al-Afkar ad-Dawliyah, n.d.), 465. See Muhammad bin Isa bin Saurah, Sunan at-Tirmidzi, volume 4 (Riyad: Maktabah al-Ma'rifah, n.d.), 231. See Jalaluddin as-Suyuthi, Sunan an-Nasa'i, volume 8 (Beirut: Dar al-Ma'rifah, n.d.), 215. See al-Bukhari, Shabih al-Bukhari, volume 7, 82. See Ibnu 
"From Nadir bin Anas bin Malik said, I sat next to Ibnu Abbas, then he began to claim, Rasulullah did not say something until a man asked him, really I am a man who painted this picture, Ibnu Abbas said to him, approached him, then a man approached, then Ibnu Abbas explained that I heard Rasulullah said, "Whoever paints a picture in the world, he is burdened to blow soul to it (painting or picture) on the day of Judgment, even though he not blowing soul (create the images or paintings) painted at the time of life in the world." (H.R. Muslim).

When viewed from the path of narration of the hadith by using i'tibar at-takbrij, it is clear as in the following scheme:

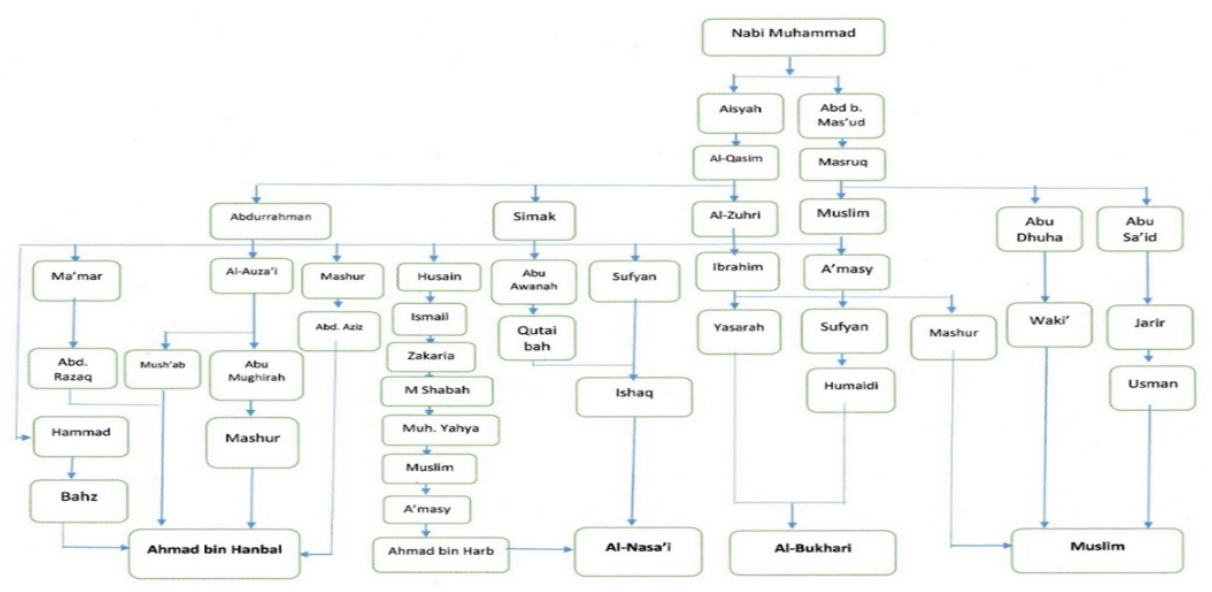

Based on the scheme of the sanad path, the hadith about the prohibition of painting using the word al-mushawwirun is narrated by two companions of the Prophet namely Abdullah bin Mas'ud (main hadith) which was made the basis by Syuhudi Ismail, and 'Aisyah asysyabid (supporters) and two muttabi' from tabi'in namely Masruq and al-Qasim. So, this hadith can be concluded to fall into the category of Ahad hadith which is Aziz with a valid sanad. Whereas when using the word shawwara, it is found that the hadith is narrated by three companions of the Prophet, namely Abu Hurairah, Ibnu

Hanbal, Musnad al-Imam Ahmad bin Hanbal, volume 3, 359. 
Abbas, and Abdullah bin Umar so that this hadith falls into the category of Ahad hadith which is Masyhur with valid sanad.

According to Syuhudi Ismail, because of the many hadith of the Prophet which forbade the making and display painting of animate creatures, namely humans and animals, it is not surprising that the textual understanding of hadith is quite a lot of support, especially in classical times. Therefore, it is understandable that this is the background of classical painter directing their paintings into calligraphy, plants and natural scenery.

The hadiths which contain the prohibition of painting and displaying the animate creature's paintings are stated by the Prophet in his capacity as the Messenger of Allah. Why is that, because in the hadith it was stated about the news of the future fate of painters on the day of judgment. Such information can only be stated by the Prophet in his capacity as a messenger of Allah.

The prohibition on painting and displaying the paintings put forward by the Prophet actually had a legal background or legal cause ('illah al-hukm). According to him, at the time of the Prophet, society had not been separated from the belief of associating partners with Allah namely worship of statues and the like. In his capacity as an apostle, the Prophet Muhammad strove so that Muslims would be free from polytheism. One of the ways is to issue a ban on producing and displaying paintings. The threat of severe torture mentioned in the above hadith is not only for those who produce paintings, but also for those who display them.

If 'illah al-hukm is so, then when Muslims are no longer worried about falling into polytheism, especially in the form of worship of paintings, then making and displaying paintings is allowed based on the rules of ushul al-figh which states:

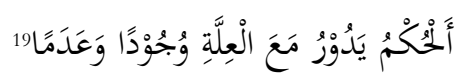

${ }^{19}$ Muhammad bin Ali bin Muhammad asy-Syaukani, Al-Qaul al-Mufiq fi Adillat alIjtihad wa at-Taqlid (Mesir: Mushthafa al-Babi al-Halabi, 1347), 72. See Zakariya bin Ghulam Qadir al-Bakistani, Min Usbul al-Figh 'ala Manhaj Abl al-Hadi (Jeddah: Dar al-Kharaz, 2002), 48. 
"The law revolves around its 'illah (background), existence and absence."

According to Syuhudi Ismail, the law was determined by its 'illah. If 'illah exists, the law exists, but if 'illah does not exist then the law becomes non-existent. This is where the "excesses" of contextual understanding can arise. For example, paintings painted at a time when people have faith in worshiping a statue are syirk. On another occasion, when people's attitudes have changed, the painting is then worshiped by people, so the question arises, is the painter apart from the responsibility for worshiping the painting? The answer is that the wrong person is the one who worships the painting; however, the painter cannot avoid responsibility.

\section{Analyze the Understanding of $M$. Syuhudi Ismail about the Hadith that Threat the Tashwir Actors (Painter)}

When analyze Syuhudi Ismail's understanding on the hadith regarding the threat to the perpetrators of tashwir (al-mushawmir) is carried out, it seems that he uses a historical sociological approach. This approach serves to see the Prophet's hadith delivered in the past, then apply it to the present. He tried to understand the hadith by looking at al-wurud (because of the coming) of the Prophet's hadith as in the hadith about the threat to the painter. From this aspect, he then saw the figure of Muhammad whether he was a Prophet or an apostle. According to him that the Prophet in the hadith period was conveyed that his capacity as an apostle of Allah so that the hadith applies to his people. Therefore, this historical aspect becomes legitimacy for Syuhudi to determine illah al-hukm (legal cause) in determining whether or not to paint even though in the hadith textually shows the prohibition of painting.

In the past, people made the painting as an object of worship, so this is where the apostle forbade it as the aforementioned hadith. This opinion was also expressed by M. Quraish Shihab by quoting 
Ibn Asyur's opinion that Islam strictly forbade statues that have been ingrained in the souls of Arabs and other than Arabic, which contain elements of syirk, including hadith which prohibit painting, drawing and sculpting sculptures. It means that he forbids drawing and painting that have an element of shirk to Allah so that if it does not fall into the element of shirk, it is not be a problem. ${ }^{20}$ This is the same as the opinion of M. Syuhudi Ismail by looking at legal reasons. This is certainly different from the opinion of an-Nawawi in his Syarh book that among us and other scholars argue, painting animal drawings is a terrible prohibition because it includes acts of great sin so that the perpetrators threatened with a tremendous threat and equaling Allah's creation both pictures or paintings of animals on clothes, floors, money, walls and others. The picture of the tree and others that are lifeless is not illegal. ${ }^{21}$ The knowledgeable people say that drawing or painting animate objects such as animals and other has makruh laws based on hadith on a threat to the perpetrators of tashwir. They reasoned with hadith narrated from Aisyah from the Prophet saw. said, "The most terrible man of his torment on the Day of Resurrection is al-mushawwir (the painter) and he is told to live what you created."22

Muhammad al-Ghazali said emphatically that images of animals in curtains or coverings, roofs or ceilings were illegitimate except for pictures of trees, pictures on the bed, in sandals that had no images and under the pillow. This was based on the hadith originating from Aisyah that he saw sutrah pictured in his house, and then he turned away from her and told Ayesha to make it a bed. The use of images of animals, pictures of men and images of

${ }^{20}$ M. Quraish Shihab, Wawasan Al-Qur'an: Tafsir Tematik atas Pelbagai Persoalan Umat (Bandung: Mizan, 2014), 518-519.

${ }^{21}$ Abu Zakariya Yahya bin Syarf bin Mari an-Nawawi, Syarh an-Nawawi 'ala Muslim, volume 16 (Kairo: al-Mathba'ah al-Mishriyyah bi al-Azhar, 1929), 81.

${ }^{22}$ Ibnu Abd al-Bar, al-Istidzkar al-Jami' li Madz̧hab Fuqaha' al-Amshar wa al-Aqshar fi Ma Tashammanabu al-Muwasha min Man ar-Ra'yi wa al-Ashari (Beirut: Dar al-Qutaibah, 1993), 5.888. 
women, al-Ghazali allowed woven fabrics which were useful for use as beds. However, according to him in general the hadith shows the prohibition of painting where people who paint will be collected on the Day of Judgment will be told to blow the spirit of the picture or painting he made at the time in the world, and then he was tortured with severe torture. ${ }^{23}$ Al-Qurtubi also said that what was prohibited in the hadith was a picture of animate animals as hadith from Aisha about threats to al-mushawnirun.

The problem that arises is what is the legal picture of the photography? According to Said Ramadan al-Buthi said that the images resulting from photography were not the same as the pictures using hands. It is because camera proficiency is faster than drawing or painting to match Allah's creation. But he stated again, for caution, it is better not to distinguish between pictures or paintings with such things because the hadith is general in nature so it is better to leave it so that it is not trapped in something that is haram. ${ }^{24}$ However, Ibnu Taymiyah said that the painting in it had no element of mixing and fraud because everyone knew that what the animal was drawing was not an actual animal. Therefore, he can distinguish between images of animals and not animals so that they can draw trees, gems in clothes and walls. ${ }^{25}$

M. Syuhudi Ismail did not explain the photo of the photograph, even though the hadith about the painting is general in nature, it can cover various forms of images. But it seems, the researcher argues, after analyzing the methods used in understanding the hadith of the Prophet with a contextual approach, he saw from its historical aspects. So that the picture or photo can also be haram if worshiped. But if not, then someone may display photos of digital photographs in the home or living room. Al-Qardhawi added that photographic

\footnotetext{
${ }^{23}$ Muhammad bin Muhammad al-Ghazali, al-Wasih fi al-Madz̧hab (Kairo: Dar asSalam, 1997), 277.

${ }^{24}$ Said Ramadhan al-Buthi, Fikih Sirah (Bandung: Mizan, 2010), 507.

${ }^{25}$ Taqiyyuddin Ahmad bin Taimiyyah al-Harani, Majmu'ah al-Fatawa (al-Manshurah: Dar al-Wafa, 2005), 370.
} 
images produced from sunlight were an unknown thing at the time of the Prophet. Then it is clear as interpreted by Syekh al-Bukhait a Mufti from Egypt in his treatise al-Jawab asy-Syar'i fi Ibahat at-Tashwir Futugrafi that taking pictures with photography that is holding the shadow using known means is not included banned images. Because images or paintings that are forbidden in the hadith are manifesting and creating types of images that have not existed before, so that they can match Allah's creatures. ${ }^{26}$

This understanding of M. Syuhudi Ismail is a solution faced by future painters who are experiencing anxiety because they are threatened by torture of hell and they are even told to enliven their paintings. Therefore, Syuhudi's understanding could provide enlightenment to those who work as painters, but on the other hand it also raises the negative opinion of some people who disagree with their opinions. However, it does not mean that every painting is possible. There are several things that should not be conducted in the view of Islam, namely painting something that is pornographic and encourages lust.

\section{Factors Affecting the Pattern of Thought of Hadith of M. Syuhudi Ismail}

Factors that influence the thinking of M. Syuhudi Ismail in understanding the Prophet's hadith so that it becomes open (open minded) and accepts all inputs given by others, especially from his teacher who provides the most academic and non-academic guidance. The researcher tries to divide into two factors, namely: internal and external factors.

First, internal factors. This factor does not affect many aspects of his thinking in the field of hadith. M. Syuhudi Ismail is a person who is an expert in the field of hadith, since he was a child he was educated by his religiously devoted parents to form an obedient

${ }^{26}$ Yusuf al-Qaradhawi, Halal dan Haram, transl. Abu Said al-Falahi and Aunur Rafiq Shaleh Tamhidi (Jakarta: Rabbani Press, 2018), 128-129. 
person to Allah and His messenger. Educated by his tough father and his famous mother who is subtle so as to form two different behaviors namely firm and gentle. This is what caused him to be open and not to quickly judge a hadith textually.

Second, external factors, this factor makes a moderate M. Syuhudi Ismail and tends to be open in understanding the Prophet's hadith. Since he entered the academic level with high education and interacted more with people, especially his teacher, who always gave input and guidance to him such as M. Quraish Shihab, Said Agil Husain al-Munawwar and also Muhammadiyah figures Madjidi. In addition, he also diligently reads the books of previous scholars, which influenced the pattern of thinking and understanding of the elastic M. Syuhudi Ismail (tasabul).

When read and examined the book written by the teacher of M. Syuhudi Ismail namely Said Agil Husain al-Munawwar and Abdul Mustaqim as his students entitled Asbab al-Wurud: Studi Kritis Hadis Nabi Pendekatan Sosio-Historis-Kontekstual, both of which discuss the prohibition of the hadith of painting and the two figures using asbab al-wurud method with a historical- sociological and psychological approach which states that at that time they were forbidden to paint because they had just recovered from the disease of syirk namely associating partners with worshiping statues and so on so that the Prophet tried hard for them to truly heal from polytheism. So the context is different from now because the hadith prohibition is only traditional and temporal based on the rules of ushul figh, "al-bukmu yaduru ma'a 'illatibi wujudan wa adaman", means that the law revolves around the existence and absence of illah. So if illah changes then the law changes. This is where the flexibility and elasticity of Islamic law lies. ${ }^{27}$ On this basis, he was influenced by his teacher by constructing his thoughts that were not much different from his teacher in understanding the hadith of the Prophet.

${ }^{27}$ Said Agil Husain al-Munawwar and Abdul Mustaqim, Asbab al-Wurud: Studi Kritis Hadis Nabi Pendekatan Sosio-Historis-Kontekstual (Yogyakarta: Pustaka Pelajar, 2001), 32-35. 
This kind of hadith understanding is also conducted by Muhammad al-Ghazali by using a textual and contextual approach with his book entitled as-Sunnah an-Nabawiyah baina al-Figh wa Abl al-Hadits. Even when the hadith contradicts the Qur'an it refuses. For example the hadith about "the corps was tortured because of the crying of his family". This hadith clearly contradicts the verse of the Qur'an which says, "Someone's sin does not bear the sins of others” (Q.S. al-An'am [6]: 164). ${ }^{28}$

Another factor that made him very contextual in understanding the Prophet's hadith was because his parents themselves were neutral in organizing and not too cultured one of the two ideas of the organization that developed at that time, namely Muhammadiyah and Nahdlatul Ulama, plus he had studied to Madjidi a Muhammadiyah figure who became his teacher. So that it is strongly suspected that the thought patterns of M. Syuhudi Ismail were also influenced by him from Muhammadiyah circles. Because in the Muhammadiyah perspective pictures or paintings range depending on illah (why) and the law is divided into three parts, namely: First, pictures or paintings that aim to worship, the law is illegal based on the hadith text. Second, images or paintings that aim for teaching facilities, the law is mubah (permissible). Third, pictures or paintings that are intended as jewelry are divided into two, namely: (a) if there is no fear of bringing slander, the law is mubah; (b) if it brings two slanders; if it leads to immorality, then the law is makrub and if it leads to polytheism, the law is forbidden as a picture of the Prophets and people of inquiry, such as displaying images of K.H. Ahmad Dahlan if it is feared to bring to polytheism, the law is haram. Based on this according to Muhammadiyah, if it does not cause worship and polytheism then the law is permissible. ${ }^{29}$ M. Syuhudi Ismail also mingled with and studied with philosophers

${ }^{28}$ Muhammad al-Ghazali, Studi Kritis Hadis Nabi saw:: antara Pemahaman Tekstual dan Kontekstual (Bandung: Mizan, 1998), 29.

${ }^{29}$ Pimpinan Pusat Muhammadiyah, Himpunan Putusan Tarjih Mubammadiyah (Yogyakarta: Suara Muhammadiyah, 1967), 281. 
and history figures whose education came from Egypt and America namely Harun Nasution, he was famous for his rational thinking and was once chancellor of IAIN Syarif Hidayatullah Jakarta. ${ }^{30}$ Even though Harun did not discuss the law of painting, but at least the thought influenced the thought patterns of M. Syuhudi Ismail in understanding the Prophet's hadith with a philosophical approach, namely the historical sociological approach. Harun Nasution also supervised his dissertation with the title "Kaidah Kesahihan Sanad Hadis: Telaah Kritis dan Tinjauan dengan Pendekatan Ilmu Sejarah" to deliver him to obtain a doctorate in the field of hadith in IAIN or UIN Syarif Hidayatullah Jakarta.

Based on the wide-ranging scientific aspects surrounding and influencing the wealth of knowledge of M. Syuhudi Ismail both from the aspects of ushul figh, figh, interpretation, hadith, history, and philosophy to form a construction of thought which gave birth to textual and contextual methods of understanding hadith texts. This method is also used by Ali Mustafa Yaqub in understanding the hadith of the Prophet, saying that if the hadith cannot be understood textually, it must be understood contextually. Textual is related to the hadith which explains about unseen matters and the problem of worship of mahzah. As for what is meant contextually, he offers four ways to understand hadith, namely: (a) seeing sabab al-wurud (because of the coming of hadith); (b) local and temporal (makani wa ramani); (c) sentence causality (illah al-kalam), socio-cultural (taqalid). ${ }^{31}$ For this reason the scientific pattern and method are not much different from M. Syuhudi Islam's thinking, the difference is only Ali Mustafa Yaqub is Middle East Alumni while M. Syuhudi Ismail is an alumni of IAIN Syarif Hidayatullah Jakarta.

${ }^{30}$ Harun Nasution, Islam Rasional: Gagasan dan Pemikiran (Bandung: Mizan, 1996), 157.

${ }^{31}$ Rohmansyah, "Hadith Hermeneutic of Ali Mustafa Yaqub", KALAM 11, no. 1 (2017), 187-214. 


\section{Conclusion}

Based on the description above, it was concluded that M. Syuhudi Ismail was an expert on Indonesian hadith which was famous for being productive. His elastic thinking in understanding the Prophet's hadith, especially the hadith relating to the problem of humanity mu'amalah were problematic. One of them is the hadith of threat to painters. The hadith understood by M. Syuhudi Ismail is temporal and local only applies to the condition of the people who were just released from syirk, they painted a picture of animate then glorified and worshiped, the Prophet forbade with the threat of torment of hell. Therefore, he understands the hadith by looking at 'illah (cause) law in the hadith which is worshiping and culturing paintings or drawings so that when drawn to the present context, it is permissible for painters to aim not to worship but to make a living or economic needs in worship to Allah. 


\section{REFERENCES}

Amrulloh. "Kontribusi M. Syuhudi Ismail dalam Kontekstualisasi Pemahaman Hadis", Mutawatir: Jurnal Keilmuan Tafsir Hadis 7, no. 1 (2017).

al-Bakistani, Zakariya bin Ghulam Qadir. Min Ushul al-Fiqh 'ala Manhaj Abl al-Hadits. Jeddah: Dar al-Kharaz, 2002.

al-Bar, Ibnu Abd. al-Istidzkar al-Jami' li Madzhab Fuqaha' al-Amshar wa al-Aqshar fi Ma Tashammanabu al-Muwasha min Ma'an arRa'yi wa al-Ashari. Beirut: Dar al-Qutaibah, 1993.

al-Bukhari, Muhammad bin Isma'il bin Ibrahim bin al-Mughirah al-Ju'fi. Shahih al-Bukhari, volume 8. Beirut: Dar al-Syuq alNajah, 1422.

al-Busti, Muhammad bin Hibban bin Ahmad Abu Hatim at-Taimi. Shabih Ibnu Hibban bi Tartib Ibnu Balban, volume 13. Beirut: al-Muassasah ar-Risalah, 1993.

al-Buthi, Said Ramadhan. Fikih Sirah. Bandung: Mizan, 2010.

Fanani, Muhyar. Metodologi Studi Islam: Aplikasi Sosiologi Pengetabuan Sebagai Cara Pandang. Yogyakarta: Pustaka Pelajar, 2010.

al-Ghazali, Muhammad bin Muhammad. al-Wasith fi al-Madz̦hab. Kairo: Dar as-Salam, 1997.

al-Ghazali, Muhammad. Studi Kritis Hadis Nabi saw:: antara Pemahaman Tekstual dan Kontekstual. Bandung: Mizan, 1998.

HAM, Musahadi. HermeneutikaHadis-Hadis Hukum:Mempertimbangkan Gagasan Fazlur Rahman. Semarang: Walisongo Press, 2009.

Hanafi, Zainuddin Ibnu Najim. al-Basyr ar-Ra`iq Syarb Kanz adDaqaiq. Beirut: Dar al-Kutub al-'Ilmiyyah, 1997.

Hanbal, Ahmad bin. Musnad al-Imam Ahmad bin Hanbal, volume 42. Beirut: al-Muassasah ar-Risalah, 2001. 
al-Harani, Taqiyyuddin Ahmad bin Taimiyyah. Majmu'ah al-Fatawa. al-Manshurah: Dar al-Wafa, 2005.

Hasanah, Syarifah. "Hermeneutika Hadis Syuhudi Ismail", Hermeneutika Al-Qur'an dan Hadis, ed. Sahiron Syamsuddin. Yogyakarta: eLSAQ, 2010.

al-Husain, Abu Muslim bin al-Hajaj al-Qusyairi an-Naisaburi. Shabih Muslim, volume 1. Riyad: Bait al-Afkar ad-Dawliyyah, 1998. Ismail, M. Syuhudi. Hadis Nabi yang Tekstual dan Kontekstual. Jakarta: Bulan Bintang, 2009. Kaidah Kesabihan Sanad Hadis: Telaah Kritis dan Tinjuan dengan Pendekatan Ilmu Sejarah. Jakarta: Bulan Bintang, 2005. Muhammadiyah, Pimpinan Pusat. Himpunan Putusan Tarjih Muhammadiyah. Yogyakarta: Suara Muhammadiyah, 1967.

al-Munawwar, Said Agil Husain and Abdul Mustaqim. Asbab alWurud: Studi Kritis Hadis Nabi Pendekatan Sosio-HistorisKontekstual. Yogyakarta: Pustaka Pelajar, 2001.

an-Nasa'i, Abu Abdurrahman bin Ahmad bin Syu'aib. Sunan anNasa’i, volume 2. Beirut: Dar al-Ma'rifah, n.d.

Nasution, Harun. Islam Rasional: Gagasan dan Pemikiran. Bandung: Mizan, 1996.

an-Nawawi, Abu Zakariya Yahya bin Syarf bin Mari. Syarh an-Nawawi 'ala Muslim, volume 16. Kairo: al-Mathba'ah al-Mishriyyah bi al-Azhar, 1929.

Pimpinan Pusat Muhammadiyah. Himpunan Putusan Tarjih Muhammadiyah. Yogyakarta: Suara Muhammadiyah, 1967. al-Qaradhawi, Yusuf. al-Halalwa al-Haram fi al-Islam. Kairo: Maktabah Wahbah, 1997. . Halal dan Haram, transl. Abu Said al-Falahi and Aunur Rafiq Shaleh Tamhidi. Jakarta: Rabbani Press, 2018. 
Rohmansyah. "Hadith Hermeneutic of Ali Mustafa Yaqub", KALAM 11, no. 1 (2017): 187-214.

Saurah, Muhammad bin Isa bin. Sunan at-Tirmidzi, volume 4. Riyad: Maktabah al-Ma'rifah, n.d.

Shihab, M. Quraish. Wawasan Al-Qur'an: Tafsir Tematik atas Pelbagai Persoalan Umat. Bandung: Mizan, 2014.

Sibawaihi. Hermeneutika Alquran Fąlur Rahman. Bandung: Jalasutra, 2007.

as-Sijistani, Sulaiman bin al-Asy'ats. Sunan Abi Dawnd. Riyad: Bait al-Afkar ad-Dawliyah, n.d.

Sirry, Mun'im A. Tradisi Intelektual Islam Rekonfigurasi Sumber Otoritas Agama. Malang: Madani, 2015.

Su'aidi, Hasan. "Hermeneutika Hadis Syuhudi Ismail", RELIGIA 20, no. 1 (2017): 33-48.

Sulaiman, Fithriady Ilyas and Ishak bin Hj. "Muhammad Syuhudi Ismail (1943-1995): Tokoh Hadis Prolifik, Ensiklopedik, dan Ijtihad", Jurnal Ilmiah Islam Futura 17, no. 1 (2017): 1-33.

asy-Syaukani, Muhammad bin Ali bin Muhammad. al-Qaul al-Mufiq fi Adillat al-Ijtihad wa at-Taqlid. Mesir: Mushthafa al-Babi alHalabi, 1347.

az-Zuhaili, Wahbah. al-Fiqh al-Islami wa Adillatubu. Damaskus: Dar al-Fikr, 1984. 